\title{
Pluralisme Agama Bukan Nihilisme: Respon Untuk Kaum Fundamentalis
}

\author{
Moh. Shofan \\ Mahasiswa S3 UIN Sunan Kalijaga
}

\begin{abstract}
This article will see the problem of pluralism through multi- dimensional approach. The plural society is not only the characteristic of modern industrial society, but also the characteristic of Islamic society, since the Prophet (PBUH) era. Normatively, al-Quran clearly rejects the exclusif way of life. In todays life, admitting diversity but having no will to create harmony will cause an unendless problem. Pluralism is the divine design which must be applied in manner and action. This must not stop in the discourse, but more practical. Human being is not merely a homo pluralist, who appreciate the diversity, but homo multiculturalist, who believe that in a plural relation there must be build real actions based on equality and justice.

Kata Kunci: pluralism; klaim kebenaran; multicultural; harmoni
\end{abstract}

\section{Pendahuluan}

Era sekarang, yang disebut-sebut sebagai "era pluralisme" dalam berbagai segi kehidupan manusia; era pluralisme budaya, era pluralisme agama, era pluralisme teknologi dan begitu seterusnya. Di balik ungkapan itu terkan- dung maksud bahwasanya sangat sulit untuk mempertahankan "paradigma tunggal " dalam wacana apa pun. Semuannya serba beraneka ragam, semua- nya harus dipahami dan didekati dengan multidimensional approach. ${ }^{1}$

Masyarakat yang bersifat pluralistik, sebenarnya, tidak hanya ciri khas masyarakat industri modern. Dalam pengalaman historitas keberagamaan islam era kenaikan Nabi Muhammad masyarakat yang pluralistik secara religius telah membentuk dan sudah pula menjadi kesadaran umum pada saat itu. Keadaan demikian, sudah sewajarnya lantaran secara kronologis agama Islam memang muncul setelah terlebih dahulu didahului oleh berkembangnya agama Hindu, Budha, Kristen-Katolik, Majusi, Zoroaster, Mesir Kuno maupun agama-agama lain. Untuk itu "dialog" antar iman termasuk tema sentral yang mewarnai al-Qur'an.

Dalam tulisan ini, penulis sengaja menggunakan istilah pluralisme dan bukan pluralitassebagaimana yang digunakan oleh MUI. Menurut MUI, pluralitas itu tidak ada masalah, karena pluralitas adalah suatu kenyataan. Akan tetapi, bahwa pluralisme itu bermasalah, karena pluralisme itu suatu pemikiran yang menganggap semua agama itu sama. Karenanya, -menurut MUI- istilah 'pluralisme' itu bukan hanya tidak tepat, tetapi haram meng- gunakannya.

Pluralitas adalah istilah dalam ilmu sosial yang berarti keberagaman ber- agama, pluralisme merupakan paham yang tidak menafikan atau mengakui eksistensi agama-agama yang ada dalam masyarakat. Namun pada sosialisasi fatwa MUI, mengatakan, pluralisme adalah sebagai paham yang menghendaki bahwa setiap orang bebas memilih agama yang disenangi, karena pada dasarnya setiap agama mengandung kebenaran, yang boleh jadi ada kebenaran pada agama lain yang tidak dia anut. Mengakui pluralitas namun menafikan (mengharamkan) paham mengenai pluralisme sangat mustahil karena keduanya merupakan satu kesatuan yang tidak terpisahkan. Sama halnya memisahkan antara Islam dan muslim.

\footnotetext{
${ }^{1}$ M. Amin Abdullah, Falsafah Kalam di Era Postmodernisme (Yogyakarta: Pustaka Pelajar, 1997), h. 104 . lihat juga M. Amin Abdullah, Studi Agama: Normativitas Atau His- torisitas? (Yogyakarta: Pustaka Pelajar, 1996), h. $45 \& 72$.
} 
Konfrontasi: Jurnal Kultur, Ekonomi dan Perubahan Sosial, 3 (1) Januari 2016, 8-23

P-ISSN: 1410-881X (Print)

Moh. Shofan, Pluralisme Agama Bukan Nihilisme: Respon Untuk Kaum Fundamentalis

DOI: -

http://www.konfrontasi.net/index.php/konfrontasi2

Dua tafsir mengenai pluralisme di atas, sangat bertentangan antara penaf- siran lewat kaca mata ilmu sosial dengan kaca mata milik MUI. Ironisnya, yang berkembang pada masyarakat awam adalah gambaran pluralisme pada ilmu sosial, namun menggunakan pengertian yang dikembangkan oleh MUI, sehingga terjadi pergeseran makna tentang pluralisme yang sebenarnya.

Menurut Budhy Munawar Rahman, ${ }^{2}$ pembedaan yang terlalu keras semacam itu diakibatkan oleh ketidakmengertian mengenai pluralisme itu sendiri. Bukan karena suatu ideologi. Misalnya, mau membuat suatu kecenderungan agama baru dengan menyatukan semua agama. Pluralisme itu pertama kali sebenarnya adalah suatu komitmen. Karena dalam kenyataan masyarakat itu plural (pluralitas), maka kita menghormati kepluralan, kemajemukan, dan keberbedaan itu. Jadi keberbedaannya yang ditekankan. Penghormatan terhadap perbedaan itu yang ditekankan. Sekaligus kita punya komitmen bersama bahwa dalam keberbedaan itu kita mau membangun sesuatu yang mempertemukan kita semua, yaitu civil society. Karena civil society itu masyarakat dari berbagai macam kelompok, ras, suku, agama, atau apa saja. Semuanya bisa hidup dalam suatu masyarakat. Yang disebut civil society adalah warga negara.

Amat sangat disayangkan jika MUI sebagai lembaga keagamaan dengan otoritasnya itu mereka bertindak sewenang-wenang yang berimplikasi pada tindakan yang mengarah pada otoritarianisme. Penulis sungguh mengecam tindakan itu yang sangat tidak manusiawi. Kalau MUI membuat fatwa tentang pluralisme, berarti dia sudah menutup kemungkinan diskursus atau 'problem discourse'. Karena dengan atas nama otoritas, MUI sebagai Majelis Ulama punya otoritas tinggi, mereka menutup diskursus ini dengan mengatakan yang benar adalah ini. Pluralisme yang ditekankan oleh penulis adalah teologi pluralisme. Yakni paham kita mengenai agama orang lain itu bagaimana. Mulai dari yang eksklusif sama sekali, sampai yang membuka diri sama sekali.

Paham pluralisme (dalam ilmu sosial) agama sesungguhnya merupakan kehendak Allah SWT. Dalam Islam sendiri secara normatif mengakui hak dan keberadaan pengikut agama lain (QS 2 : 256, QS 109 : 6). Secara otomatis inilah prinsip dasar doktrin Islam mengenai pluralisme sebagai kehendak Allah SWT. Hingga sudah sewajarnya umat Islam menerima eksistensi pluralisme agama (dalam ilmu sosial) secara positif sebagai sebuah aturan dan kehendak Allah SWT yang tidak bisa dihindari.

\section{Islam dan Pluralisme}

Nurcholish Madjid, dalam "Masyarakat Madani dan Investasi Demokrasi: Tantangan dan Kemungkinan" - sebagaimana yang dikutip Budhy Munawar Rahman- mengatakan bahwa Pluralisme tidak dapat dipahami hanya dengan mengatakan bahwa masyarakat kita majemuk, beraneka ragam, terdiri dari berbagai suku dan agama, yang justru hanya menggambarkan kesan fragmentasi, bukan pluralisme. Pluralisme juga tidak boleh dipahami sekadar sebagai "kebaikan negatif" (negative good), hanya ditilik dari kegunaannya untuk menyingkirkan fanatisisme (to keep fanaticism at bay). Pluralisme harus dipahami sebagai "pertalian sejati kebinekaan dalam ikatan-ikatan keadaban" (genuine engagement of diversities within the bonds of civility). Bahkan pluralisme adalah juga suatu keharusan bagi keselamatan umat manusia, antara lain melalui mekanisme pengawasan dan pengimbangan yang dihasilkannya. Dalam Kitab Suci justru disebutkan bahwa Allah menciptakan mekanisme pengawasan dan pengimbangan antara

\footnotetext{
${ }^{2}$ Lihat, Budhy Munawar Rachman, "Teologi Pluralisme di Persimpangan Jalan,” wawancara di Jaringan Islam Emansipatoris, www.islamemansipatoris.com.
} 
Konfrontasi: Jurnal Kultur, Ekonomi dan Perubahan Sosial, 3 (1) Januari 2016, 8-23

P-ISSN: 1410-881X (Print)

Moh. Shofan, Pluralisme Agama Bukan Nihilisme: Respon Untuk Kaum Fundamentalis

DOI: -

http://www.konfrontasi.net/index.php/konfrontasi2

sesama manusia guna memelihara keutuhan bumi, dan merupakan salah satu wujud kemurahan Tuhan yang melimpah kepada umat manusia.

"Seandainya Allah tidak mengimbangi segolongan manusia dengan sego- longan yang lain, maka pastilah bumi hancur; namun Allah mempunyai kemurahan yang melimpah kepada seluruh alam.”(QS. al-Baqarah/ 2:251). ${ }^{3}$

Salah satu kesadaran yang sangat berakar dalam pandangan seorang Muslim ialah bahwa agama Islam adalah sebuah agama universal, untuk sekalian umat manusia. Pokok pangkal kebenaran universal yang tunggal itu, menurut Nurcholish Madjid, ialah paham Ketuhanan Yang Maha Esa atau Tawhid (secara harfiah) berarti 'memahaesakan', yakni memahaesakan Tuhan). ${ }^{4}$ Berdasarkan paham ke-tawhid-an inilah, al-Qur'an mengajarkan paham kemajemukan keagamaan (religious plurality), yang dewasa ini menjadi tema penting dalam studi agamaagama dan pembicaraan mengenai teologi agama-agama. Dalam pandangan teologi Islam, sikap ini dapat ditafsirkan sebagai suatu harapan kepada semua agama yang ada: bahwa semua agama itu pada mulanya menganut prinsip yang sama, dan karena alasan inilah al-Qur'an mengajak kepada titik pertemuan (kalimat- un sawa'). ${ }^{5}$

Konsep kalimatun sawa' menurut Nurcholish Madjid, adalah kalimat, ide, atau prinsip yang sama, yakni ajaran bersama yang menjadi "common platform" antara berbagai kelompok manusia. Implikasi dari kalimatun- sawa ini menurut al-Qur'an adalah: Siapapun dapat memperoleh 'kese- lamatan' asalkan dia beriman kepada Allah, kepada hari Kemudian, dan berbuat baik - tiga pertanda dari orang-orang yang selamat menurut al- Qur'an yang dikatakan dalam dua ayat yang persis hampir sama. "Sesung- guhnya orang-orang Mukmin, orang-orang Yahudi, orang-orang Nasrani dan orang-orang Shabi' in, siapa saja yang beriman kepada Allah dan Hari Kemudian serta berbuat kebajikan, bagi mereka pahala dari Tuhan mereka, tidak ada kekhawatiran terhadap mereka, dan tidak pula mereka akan bersedih hati."6

Pemahaman pluralisme seperti di atas berkaitan dengan pemahaman mengenai hakikat universalisme agama. Bahwa semua agama pada dasarnya secara esoterik disatukan dengan kebajikan universal, yang menjadikan setiap agama sama-sama memiliki pandangan dasar yang sama tentang realitas yang absolut (absolut reality). ${ }^{7}$

Menurut Prof Dr. Abdulaziz Sachedina, guru besar Studi Agama di Univer- sitas Virginia, pluralisme adalah "pondasi kehidupan bagi agama-agama" (ashl al-hayat bayna al-adyan). Kita bisa melacak ayat-ayat Alqur'an yang mendukung pluralisme ini sebagai satu rahasia dari lautan rahasia Allah. Salah satunya, Jika Tuhanmu menghendaki maka kalian akan dijadikan umat satu. Ternyata Allah tidak berkehendak untuk menyatukan umat

\footnotetext{
${ }^{3}$ Nurcholish Madjid, "Masyarakat Madani dan Investasi Demokrasi: Tantangan dan Kemungkinan", Republika, 10 Agustus 1999. Periksa juga, Budhy Munawar Rahman, Islam Pluralis Wacana Kesetaraan Kaum Beriman (Jakarta: Paramadina, 2001 ), h. 31.

${ }^{4}$ Nurcholish Madjid, Islam Doktrin dan Peradaban Sebuah Telaah Kritis tentang Masalah Keimanan, Kemanusiaan dan Kemodernan (Jakarta: Paramadina, 1992), h. 178.

${ }^{5}$ Lihat QS. Ali ‘Imran/3: 6. Lihat juga, misalnya QS Yunus: 99, 'Jika Tuhanmu menghendaki, tentulah beriman semua orang yang berada di muka bumi ini seluruhnya. Maka apakah kamu (hendak) memaksa manusia supaya mereka menjadi orang-orang yang beriman?.' Hal senada juga terdapat dalam QS An-Nahl: 93, 'Dan kalau Allah menghendaki, niscaya Dia menjadikan kamu satu umat saja. Tetapi Allah menyesatkan siapa yang dikehendakiNya dan memberi petunjuk kepada siapa yang dikehendaki-Nya. Dan sesungguhnya kamu akan ditanya tentang apa yang kamu perbuat'”.

${ }^{6}$ Lihat QS. al-Baqarah/2:62. lihat juga ayat yang mirip sekali QS. al-Maidah/5:69.

${ }^{7}$ Lihat, Siti Nadroh, Wacana Keagamaan dan Politik Nurcholish Madjid (Jakarta: PT Raja Grafindo Persada, 1999), h. 115 .
} 
Konfrontasi: Jurnal Kultur, Ekonomi dan Perubahan Sosial, 3 (1) Januari 2016, 8-23

P-ISSN: 1410-881X (Print)

Moh. Shofan, Pluralisme Agama Bukan Nihilisme: Respon Untuk Kaum Fundamentalis

DOI: -

http://www.konfrontasi.net/index.php/konfrontasi2

manusia. Nah, keragaman agama di sini yang disinyalir ayat tadi merupakan rahasia dan kehendak Allah. Dan pluralisme sebagai dasar kehidupan semua agama mengajak kita membuka dan memahami rahasia Allah itu. Kera- gaman agama sebagai rahasia Allah meliputi juga agama-agama lain yang biasa disebut "agama-agama Ibrahimi" . Pluralisme sendiri mengakui adanya tradisi iman dan keberagamaan yang berbeda antara satu agama dengan agama lainnya. ${ }^{9}$

Pengakuan terhadap pluralisme agama dalam sebuah komunitas sosial menjanjikan dikedepankannya prinsip inklusivitas (keterbukaan) - suatu prinsip yang mengutamakan akomodasi dan bukan konflik- di antara mereka. Sebab, pada dasarnya masing-masing agama mempunyai berbagai klaim kebenaran yang ingin ditegakkan terus, sedangkan realitas masya- rakat yang ada terbukti heterogen secara kultural dan religius. Oleh karena itu, inklusivitas menjadi penting sebagai jalan menuju tumbuhnya kepekaan terhadap berbagai kemungkinan unik yang bisa memperkaya usaha manusia dalam mencari kesejahteraan spiritual dan moral. Realitas pluralitas yang bisa mendorong ke arah kerja sama dan keterbukaan itu, secara jelas telah diserukan oleh Allah Swt dalam QS. Al-Hujurat ayat 14. Dalam ayat itu, tercermin bahwa pluralitas adalah sebuah kebijakan Tuhan agar manusia saling mengenal dan membuka diri untuk bekerja sama.

Pandangan normatif ini jelas akan mendorong umat Islam untuk meng- hargai kemajemukan keagamaan lewat sikap-sikap toleransi, keterbukaan dan fairness seperti dicerminkan dalam konsep tentang siapa yang digolongkan sebagai Ahli Kitab (Ahl Kitab). Tema pokok yang merupakan dasar pemersatu ketiga agama ini disajikan secara jelas dalam al-Qur'an. Seperti yang ditunjukkan oleh Fazlur Rahman, pada bagian awal dari Qur'an bermacam-macam Nabi yang berbicara kepada bermacam-macam orang diakui, "namun pewartaan mereka adalah universal dan sama." Warta yang disampaikan oleh nabinabi yang berbeda, Abraham, Musa, Yesus, dan lain- lain, semuanya berasal dari sumber satu-satunya yang oleh Qur'an disebut dengan berbagai nama "Asal Kitab" (43:4; 13:39) dan "kitab yang terlin- dung" (56:78). Karena semua warta Nabi berasal dari sumber tunggal, maka menurut Muhammad semua orang berkewajiban untuk mengimani semua warta ilahi. Jadi Muhammad terpaksa menyatakan dalam Qur'an bahwa dia tidak saja beriman pada Taurat dan Injil tetapi juga "Aku beriman pada Kitab apa aja yang diturunkan Allah" (42:15). 12 Menurut Qur'an, kebenaran dan bimbingan Allah tidak dibatasi melainkan tersedia secara universal bagi semua orang: "Karena tiap-tiap bangsa mempunyai seorang pemimpin" $(13: 7)$.

\footnotetext{
${ }^{8}$ Dalam konteks agama Yahudi dan Kristen, Alqur'an menyebut mereka sebagai Ahli Kitab; pemeluk agama yang memiliki kitab wahyu. Meskipun al-Qur'an juga mengakui mereka "memalsukan kitab sucinya", namun Alqur'an tetap menyebut mereka sebagai Ahli Kitab; yang wajib diterima keberadaannya dan dihormati. Di ayat lain dalam surat Yunus: 99, "Dan jika Tuhanmu menghendaki, pastilah semua manusia di muka bumi akan beriman. Lalu apakah kamu (wahai Muhammad) ingin memaksakan manusia untuk beriman?" Adalah tidak masuk nalar Alqur'an jika membenci dan memaksa seseorang untuk beriman. Secara khusus ayat ini ditujukan kepada Rasulullah Saw, karena beliau tidak dibebani oleh Allah untuk bertanggung jawab agar seluruh manusia masuk Islam. Dalam ayat lain juga disebutkan; lâ ikrâh fi al-dîn (tiada paksaan dalam beragama). Prinsip-prinsip tadi menunjukkan bahwa Allah tidak menginginkan pemak- saan dalam beragama. Pandangan dan sikap yang menginginkan semua umat manusia beriman atau berislam bertentangan dengan kemauan Allah yang menginginkan kera- gaman agama. Lihat, Abdulaziz Sachedina, "Negara Tidak Punya Hak Mengurusi Keimanan," www.islamlib.com.

${ }^{9}$ Lihat, Ahmad Fuad Fanani, "Islam, Pluralisme, dan Kemerdekaan Beragama," www.islamlib.com.
} 
Konfrontasi: Jurnal Kultur, Ekonomi dan Perubahan Sosial, 3 (1) Januari 2016, 8-23

P-ISSN: 1410-881X (Print)

Moh. Shofan, Pluralisme Agama Bukan Nihilisme: Respon Untuk Kaum Fundamentalis

DOI: -

http://www.konfrontasi.net/index.php/konfrontasi2

Fazlur Rahman berpendapat bahwa kata Kitab sering digunakan dalam Qur'an bukan untuk mengacu pada suatu kitab khusus yang diwahyukan "melainkan sebagai suatu istilah generasi yang menunjukkan totalitas wahyu Ilahi (misalnya, 2:213)". Gagasan mengenai satu wahyu a priori ini dikaitkan dalam Qur'an dengan gagasan mengenai bangsa manusia yang semula bersatu.

"Manusia adalah satu umat. Allah membangkitkan para nabi sebagai pengemban berita baik dan sebagai juru ingat; dan bersama mereka Dia menurunkan kitab dengan kebenaran, agar kitab ini dapat meng-adili di antara manusia, mengenai hal yang tentangnya mereka berselisih. Dan tak ada yang berselisih tentang itu (yaitu, menyangkut kebenaran) kecuali mereka yang telah diberi kitab itu, sesudah tanda bukti datang kepada mereka, karena saling iri hati di antara mereka." (QS.Al-Baqarah (2):213).

Menurut Qur'an, pada mulanya manusia bersatu, namun berselisih karena mereka saling iri hati. Beberapa Muslim melihat perpecahan ini sebagai akibat dari adanya bermacam-macam versi dari "satu Kitab" yang diper- kenalkan oleh nabi-nabi yang berbeda. Mengapa wahyu para nabi harus bertindak sebagi kekuatan pemecah tampaknya tidak dapat dijawab, kecuali mengatakan bahwa itu adalah sebuah misteri yang dapat diatasi Allah kalau Allah menghendakinya. Fakta bahwa Allah tidak mengatasinya dijelaskan sebagi pemberi peluang bagi bermacam-macam agama untuk bersaing satu sama lain dalam hal kebaikan.

"Jika Allah menghendaki, niscaya ia akan membuat kamu satu umat, tetapi Ia akan menguji kamu dengan apa yang Ia berikan kepada kamu. Maka berlomba-lombalah dalam kebaikan. Kepada Allah-lah kamu akan kembali lalu Ia akan memberitahukan kepada kamu (kebenaran) apa yang kamu berselisih di dalamnya." (QS. Al-Maidah (5):48).

Dalam buku 'Fiqh Lintas Agama' dikatakan bahwa para pemeluk kitab suci: al-Qur'an, Taurat dan Injil menyadari beberapa perbedaan di antara mereka, al-Qur'an dan didukung oleh kajian keagamaan modern lebih banyak memandang adanya titik-titik persamaan dibandingkan titik-titik perbeda- annya. Maka pada prinsipnya kitab-kitab suci tersebut tidak boleh dikonfrontasikan, tetapi justru harus dicari dan dihayati dasar-dasar perte- muannya. Al-Qur'an tidak menghendaki konfrontasi serupa itu, karena Kitab suci kaum Muslim melihat dirinya sebagai kelanjutan yang konsisten dari Injil dan Taurat, bahkan kitab-kitab atau lembaran-lembaran (shuhuf) para Nabi sebelumnya.

Kenyatan bahwa al-Qur'an hadir setelah Injil mengisyaratkan adanya per- kembangan maupun perbedaan, meskipun segi persamaanya lebih asasi.

Titik persamaan antara kitab-kitab suci tidak terbatas hanya Al-Qur'an, Injil dan Taurat, tetapi juga kitab-kitab suci yang lain jauh lebih banyak diban- dingkan titik-titik perbedaanya. Mengenai Taurat dan Injil, Ibn Taimiyah mengatakan bahwa sebagian besar ajaran Kitab-kitab Suci tersebut tetap benar, dan hukum-hukum atau syari'atnya masih berlaku untuk kaum Muslim, sepanjang tidak dengan jelas dinyatakan telah di-nasakh atau diganti oleh Al-Qur'an.

Al-Qur'an melarang orang Islam berdebat dengan para penganut Kitab Suci (ahl alKitab), kecuali dengan cara yang lebih baik atau sopan. Kaum Muslim diperintahkan untuk menyatakan kepada Ahli Kitab bahwa mereka beriman kepada ajaran yang diturunkan kepada mereka sendiri, dan yang diturunkan kepada Ahli Kitab, dan bahwa Tuhan mereka dan Tuhan Ahli Kitab adalah sama, yaitu Tuhan Yang Maha Esa, dan semuanya adalah orangorang yang pasrah (muslimun) kepada Tuhan Yang Maha Esa. ( QS. 29:46).

Segi persamaan yang sangat asasi antara semua Kitab Suci adalah ajaran Ketuhanan Yang Maha Esa. Hal ini berbeda dengan persoalan kaum Musyrik yang pada zaman Nabi tinggal di 
Konfrontasi: Jurnal Kultur, Ekonomi dan Perubahan Sosial, 3 (1) Januari 2016, 8-23

P-ISSN: 1410-881X (Print)

Moh. Shofan, Pluralisme Agama Bukan Nihilisme: Respon Untuk Kaum Fundamentalis

DOI: -

http://www.konfrontasi.net/index.php/konfrontasi2

kota Makkah. Kepada mereka inilah dialamatkan firman Allah, "Katakan (Muhammad), Aku tidak akan menyem- bah yang kamu sembah, dan kamu pun tidak menyembah yang aku sembah..., bagi kamu agamamu, dan bagiku agamaku" (QS. al-Kafirun). Ayat yang sangat menegaskan perbedaan konsep "sesembahan" ini ditunjukan kepada kaum musyrik Quraisy dan bukan kepada Ahli Kitab.

Perbedaan tentang konsep "sesembahan" ini tetap ditegaskan Al-Qur'an, meskipun orang-orang Arab musyrik saat itu percaya kepada Allah. Mereka menggunakan perkataan "Allah" (Al-Lah) untuk sesembahan mereka, namun dengan pengertian yang berbeda dan menyimpang dari pengertian yang benar (QS. 43:87). Mereka percaya bahwa Allah punya banyak anak, dan "anak" Allah itu perempuan semuanya, seperti Al-Lat, Al-Uzza dan Manat (QS. 53: 19-23). Sekalipun kaum Ahli Kitab kecuali yang berbahasa Arab tidak menggunakan perkataan "Allah" untuk obyek sesembahan mereka, Al-Qur'an menyebutkan bahwa konsep Ketuhanan dalam Kitab Suci mereka sama dengan yang ada dalam Al-Qur'an.

Hal itu menunjukkan bahwa dalam pengertian yang benar tentang Tuhan, masalah nama bukanlah hal yang asasi; yang asasi ialah pengertiannya. Oleh karena itu ketika Nabi SAW. memperkenalkan nama Tuhan sebagai al- Rahman, orang-orang menolak, karena mereka tidak tahu, dan tidak pernah mendengar perkataan itu. Reaksi penolakan terekam dalam Kitab Suci, dalam suatu firman yang bernada polemis: Katakan (Muhammad), "seluruh Dia itu Allah atau al-Rahman, apapun yang kamu seru, bagi-Nyalah nama-nama yang baik..." (QS. 17:110).

Dan atas dasar persamaan tersebut, Al-Qur'an memuat perintah Allah kepada Nabi saw. agar berseru kepada semua penganut kitab suci untuk berkumpul dalam titik kesamaan, yakni Ketuhanan Yang Maha Esa (QS. 3:64). Bahkan kepada kaum Yahudi dan kaum Nasrani pun diserukan untuk mentaati ajaran-ajaran yang ada dalam kitab-kitab suci mereka, sebab mereka yang tidak menjalankan ajaran yang diturunkan Allah adalah orang- orang kafir, orang-orang zalim (dialamatkan kepada kaum Yahudi), dan mereka itu orang-orang fasik (dialamatkan kepada kaum Nasrani) (QS. 5:44- 47).16

Paham pluralisme (dalam ilmu sosial) agama sesungguhnya merupakan kehendak Allah SWT. Dalam Islam sendiri secara normatif mengakui hak dan keberadaan pengikut agama lain (QS. 2: 256, QS. 109: 6). Secara otomatis inilah prinsip dasar doktrin Islam mengenai pluralisme sebagai kehendak Allah SWT. Hingga sudah sewajarnya umat Islam menerima eksistensi pluralisme agama (dalam ilmu sosial) secara positif sebagai sebuah aturan dan kehendak Allah SWT yang tidak bisa dihindari.

Pluralisme adalah fakta sosial yang selalu ada dan telah menghidupi tradisi agama-agama. Walau demikian, dalam menghadapi dan menanggapi kenyataan adanya berbagai agama yang demikian pluralistik itu, agaknya setiap umat beragama tidaklah monolitik. Mereka cenderung menempuh cara dan tanggapan yang berbeda-beda, yang jika dikategorisasikan terbelah menjadi dua kelompok yang saling berhadap-hadapan. 17

Pertama, kelompok yang menolak secara mutlak gagasan pluralisme agama. Mereka biasanya disebut sebagai kelompok eksklusivis. Dalam memandang agama orang lain, kelompok ini sering kali menggunakan standar-standar penilaian yang dibuatnya sendiri untuk memberikan vonis dan menghakimi agama lain. Secara teologis, misalnya, mereka beranggapan bahwa hanya agamanyalah yang paling otentik berasal dari Tuhan, sementara agama yang lain tak lebih dari sebuah konstruksi manusia, atau mungkin juga berasal dari Tuhan tapi telah mengalami perombakan dan pemalsuan oleh umatnya sendiri. Mereka memiliki 
Konfrontasi: Jurnal Kultur, Ekonomi dan Perubahan Sosial, 3 (1) Januari 2016, 8-23

P-ISSN: 1410-881X (Print)

Moh. Shofan, Pluralisme Agama Bukan Nihilisme: Respon Untuk Kaum Fundamentalis

DOI: -

http://www.konfrontasi.net/index.php/konfrontasi2

kecenderungan membenarkan agamanya, sambil menyalahkan yang lain. Memuji agama diri sendiri seraya menjelekkan agama yang lain. Agama orang lain dipandang bukan sebagai jalan kese- lamatan paripurna. Mereka mendasarkan pandangan-pandangannya itu pada sejumlah ayat di dalam al-Quran. Misalnya, [1] QS. Ali Imran (3): 85, [2] QS. Ali Imran (3): 19 [3] QS Al-Maidah (5): 3. [4] QS An-Nisa (4): 144.

Kedua, kelompok yang menerima pluralisme agama sebagai sebuah kenyataan yang tak terhindarkan. Kelompok ini biasanya berpandangan bahwa agama semua nabi adalah satu. Mereka menganut pandangan tentang adanya titik-titik persamaan sebagai benang merah yang mempersam- bungkan seluruh ketentuan doktrinal yang dibawa oleh setiap nabi. Bagi kelompok kedua ini cukup jelas bahwa yang membedakan ajaran masingmasing adalah dimensi-dimensi yang bersifat teknis-operasional bukan yang substansialesensial, seperti tentang mekanisme atau tata cara ritus peribadatan dan sebagainya. Terdapat ayat yang menjadi menu favorit di kalangan kelompok kedua ini. Misalnya, [1] QS. Al-Kafirun (109):6 [2] QS. Al-Baqarah (2): 256. [3] QS. Al-Maidah (5): 69, [4] QS. AlAn'am (6): 108.

Karenanya dalam menyikapi dua kelompok yang berbeda pendapat di atas, kiranya diperlukan kearifan dalam melakukan pembacaan (penafsiran) terhadap teks-teks al-Qur'an. Sehingga klaim-klaim kebenaran tidak hanya dimonopoli oleh kelompok tertentu.

Secara dialektis dan hermeneutis, Al-Qur'an memberikan penawaran yang bersifat terapis dari kecenderungan umat beragama yang selalu ingin menuntut truth claim secara sepihak. AlQur'an memberikan jawaban yang sangat tegas pernyataan-peryataan umat beragama yang bersifat eksklusif tersebut. Petunjuk bukanlah fungsi dari kaum-kaum tertentu tetapi dari Allah swt dan manusia-manusia yang saleh; tidak satu kaum pun dapat mengatakan (mengklaim) bahwa merekalah yang telah diangkat Allah swt dan yang telah memperoleh petunjuk-petunjukNya; keseluruhan argu- mentasi Al-Quran menentukan ide pengangkatan dan pengakuan "keselamatan" secara sepihak tersebut:

"Setelah mencoba Ibrahim dengan beberapa perintah dan menyem- purnakannya, Allah berkata (kepadanya), "Aku akan mengangkat engkau menjadi pemimpin umat manusia." Ibrahim bertanya, "Bagaimanakah dengan anak cucuku?" dan Dia (Allah) menjawab, "ke Dalam janji-Ku tidak tercakup orang-orang yang aniaya."

Itulah kaum di zaman dahulu bagi mereka apa-apa yang mereka usahakan dan bagi kalian (wahai kaum Muslimin) apa-apa yang kalian usahakan. Kepada mereka tidak ditanyakan mengenai apa-apa yang telah mereka usahakan.

Secara normatif-doktrinal, Al-Qur'an dengan tegas menyangkal dan menolak sikap eksklusif dan tuntutan truth claim secara sepihak yang berlebihan, seperti biasa melekat pada diri para penganut agama-agama (termasuk di dalamnya para penganut agama Islam). AlQur'an berkali-kali mengakui adanya manusia-manusia yang saleh di dalam kaum-kaum tersebut, yaitu Yahudi, Kristen, dan Shabi'in seperti pengakuan akan adanya manusia yang beriman di dalam Islam:

"Orang-orang beriman (orang-orang Muslim), orang-orang Yahudi, orang-orang Kristen, dan orang-orang Shabi'in yang percaya kepada Allah dan hari kiamat, serta melakukan amal kebajikan akan memperoleh ganjaran dari Tuhan mereka, tidak ada sesuatu pun yang harus mereka khawatirkan, dan mereka tidak akan berduka."19

Menurut Fazlur Rahman, hampir seluruh mufassir Muslim (para penulis tafsir) dengan sia-sia telah berusaha untuk tidak menerima maksud yang begitu jelas dinyatakan oleh kedua ayat tersebut di atas: bahwa orang-orang dari kaum dan pengikut agama yang mana pun juga 
Konfrontasi: Jurnal Kultur, Ekonomi dan Perubahan Sosial, 3 (1) Januari 2016, 8-23

P-ISSN: 1410-881X (Print)

Moh. Shofan, Pluralisme Agama Bukan Nihilisme: Respon Untuk Kaum Fundamentalis

DOI: -

http://www.konfrontasi.net/index.php/konfrontasi2

mempercayai Allah swt dan hari kiamat, serta melakukan amal kebajikan akan memperoleh kese- lamatan.

Kebanyakan para penulis tafsir Al-Qur'an mangatakan bahwa yang di maksud dengan orang-orang Yahudi, Kristen dan Shabi'in di dalam ayat- ayat tersebut adalah orang-orang Yahudi, Kristen, dan Shabi' in yang telah masuk Islam. Penafsiran seperti ini jelas sekali tidak tepat - untuk tidak mengatakan salah- karena seperti yang terlihat di dalam ayat-ayat tersebut, orang-orang Muslim adalah yang pertama di antara keempat kelompok “orang-orang yang percaya kepada ...". Selanjutnya, para penulis tafsir Al- Qur'an tersebut mengatakan, mungkin pula yang dimaksud dengan orang- orang sebelum kedatangan Nabi Muhammad saw. Inilah, menurut Fazlur Rahman, yang lebih salah lagi. Terhadap pernyataan orang-orang Yahudi dan Kristen bahwa di akhirat nanti mereka saja yang akan memperoleh keselamatan, Al-Qur'an berkata:

"Sebaliknya, yang berserah diri kepada Allah dan melakukan amal- kebajikan akan memperoleh pahala dari Tuhannya, tidak ada sesutau pun yang harus mereka khawatirkan dan dia pun tidak akan berduka."

Bahkan ada Mufassir/ulama, yang mengatakan bahwa ajaran-ajaran para Nabi sebelum Nabi Muhammad tidak berlaku lagi karena, bagi meraka, Al- Qur'an merupakan wahyu Ilahi terakhir yang telah menghapus dan mem- batalkan ajaran sebelumnya.

Namun, ada pula ulama yang berpendapat bahwa ajaran Nabi Musa dan Isa as tetap berlaku dan sah. Salah seorang pakar Islam kontemporer, Mahmoud Ayyoub, melontarkan kritik pada perkembangan teologi dan hukum Islam yang menetapkan secara pasti doktrin penghapusan ajaran-ajaran Yahudi dan Kristen oleh Al-Qur'an. Menurut Ayyoub, Al-Qur'an tidak menetapkan bahwa ia telah menghapus keabsahan Taurat dan Injil, demikian Nabi Muhammad tidak mensyaratkan kelompok ahl al-Kitab untuk mening-galkan agama mereka sebagai imbalan untuk hidup berdampingan dan bersama-sama dengan umat Islam.

Tetapi, ayat-ayat inklusif itu selalu diklaim oleh penafsir eksklusif, telah dibatalkan (dinaskh) oleh berbagai ayat yang mengait-ngaitkan ahli kitab dengan kekafiran. Karena itu, untuk mematahkan argumen pembatalan tersebut, perlu kiranya di sini dijelaskan agak rinci mengenai kenyataan bahwa Al-Qur'an tidak menetapkan ahli kitab sebagi kafir.

Seperti dimaklumi, Al-Qur'an tak pernah langsung memberikan predikat kafir (dengan kata sifat/ isim Fa'il) kepada ahli kitab. Memang ada beberapa predikat kafir yang secara tidak lagsung ditujukan kepada mereka. Tetapi sebagaimana, telah diperiksa Farid Essack, beberapa predikat ini selalu disertai dengan ungkapan-ungkapan pengecualian seperti ungkapan "sebagian", "kecuali" dan sebagainya. Atau banyak kata kekafiran (kata benda/ mashdar) yang dinisbatkan kepada mereka, tetapi dibarengi dengan ungkapan eksepsional seperti itu (lihat, misalnya, Qs. 2:105; 12:109; 5:78 \& 110; 59:2; 98:1\&6; 3:69-71\&110). Dipihak lain, Al-Qur'an secara eksplisit membedakan antara golongan kuffar (plural dari kata kafir) dan ahli kitab (Qs. 5:56). Ini semua menunjukan bahwa Al-Qur'an tak pernah menetapkan ahli kitab sebagi kafir.

Terlebih dari Al-Qur'an membagi umat yang pernah disapanya menjadi "tiga golongan”. Pertama, mereka yang membangkang Nabi terdahulu dan juga Nabi saw. Mereka ini diancam akan mendapatkan "kemurkaan di atas kemurkaan", setimpal dengan dua kali pembangkangnya, yakni kepada Nabi saw dan Nabi terdahulu (QS. 2:90). Kedua, ahli kitab yang pasca datangnya 
Konfrontasi: Jurnal Kultur, Ekonomi dan Perubahan Sosial, 3 (1) Januari 2016, 8-23

P-ISSN: 1410-881X (Print)

Moh. Shofan, Pluralisme Agama Bukan Nihilisme: Respon Untuk Kaum Fundamentalis

DOI: -

http://www.konfrontasi.net/index.php/konfrontasi2

Nabi menerima risalah beliau dan bergabung dengan komunitas Muslim. Mereka dijanjikan Allah akan mendapatkan pahala dua kali (marratain) karena dua kali keimanannya, yakni kepada Nabi terdahulu dan juga Nabi SAW. Dengan kata lain, kelompok ini adalah ahli kitab yang telah menjadi Muslim atau masuk Islam (QS. 28:54). Ketiga, ahli kitab yang beriman kepada Nabi terdahulu, tapi tidak bergabung dengan komunitas Nabi Muhammad. Al-Qur'an tetap mengakui secara eksplisit keimanan mereka (QS. 3:113-114) Banyak mufassir eksklusif bersih keras mengatakan bahwa kelompok ahli kitab yang ditunjuk ayat ini adalah ahli kitab yang telah masuk Islam (kelompok kedua). Tetapi penafsiran ini sama sekali tidak berdasar karena soal ahli kitab yang telah masuk Islam, Al-Qur'an telah menyebutkanya di tempat lain(QS. 28:54). Dengan demikian, tak ada alasan untuk membatalkan ayat-ayat inklusif dengan berbagai ayat yang mengait- ngaitkan ahli kitab dengan kekafiran. Sebab berbagai ayat seperti itu tidak berarti menetapkan ahli kitab sebagai kafir.

Menurut Alwi Shihab, al-Qur'an menggunakan sebutan ahl al-Kitab terha- dap orangorang Yahudi dan Kristen guna menunjukkan keakraban. Ahl dalam Bahasa Arab merujuk pada hubungan keluarga, di mana tidak ada hubungan antarmanusia dengan sesamanya yang lebih dekat dari hubungan keluarga. Al-Qur'an tampaknya ingin menjelaskan bahwa antara umat Islam, Yahudi, dan Kristen terjalin hubungan yang erat bagaikan sebuah keluarga. Untuk memperkuat penegasan tersebut, yaitu agar jalinan kekeluargaan tidak terputus, banyak sekali ditemukan anjuran dalam Al-Qur'an untuk berlaku baik terhadap Ahl al-Kitab. Al-Qur'an bahkan mengajak mereka untuk menyatukan pandangan dalam rangka mencari titik temu tertentu. Di tambah lagi, Nabi Muhammad tidak henti-hentinya menjelaskan bahwa Al- Qur'an pada dasarnya sejalan dan melengkapi ajaran-ajaran Taurat dan Injil.

Dalam Al-Qur'an tersendiri, pada beberapa bagian, ditunjukkan kesaksian Ahl alkitab akan kebenaran Al-Qur'an, dan untuk itu hubungan baik dengan mereka harus dijaga dan dipertahankan. Ayat-ayat dalam Al-Qur'an yang dimaksud antara lain ( QS., 10:94): Allah berfirman "Maka jika kamu (Muhammad) berada dalam keragu-raguan tentang yangkami turunkan kepadamu, maka tanyakanlah pada orang-orang yang membaca kitab sebelum kamu. Sesungguhnya telah datang kebenaran kepadamu dari Tuhanmu, sebab itu janganlah sekali-kali kamu termasuk orang yang ragu- ragu. "Pada ayat lain Al-Qur'an memerintahkan (agar hubungan antar umat Islam dan Ahl al-kitab dapat terpelihara sebaikbaiknya) (QS. 29:46): "Dan janganlah kamu berdebat dengan Ahl al-kitab, melainkan dengan cara yang paling baik, kecuali dengan orang-orang zalim di antara mereka, dan katakanlah, 'Kami telah beriman kepada (kitab-kitab) yang di turunkan kepada kami dan diturunkan kepadamu; Tuhan kami dan Tuhanmu adalah satu; dan hanya kepada-Nya kami berserah diri. "

Bertolak dari sumber ini, kiranya dapat dipahami mengapa Islam mem- benarkan kepa-da umatnya untuk menikahi wanita Ahl al-kitab dan menerima cara penyembelihan hewan mereka (QS. Al-Maidah 5:5).

Khusus terhadap agama Kristen dari Ahl al-Kitab, Al-Qur'an memuji sikap sebagian dari mereka yang menunjukkan keakraban dan persahabatan (QS. 5:82). Terciptanya keakraban terbukti sendiri oleh Nabi atas perkawinannya dengan Maria al-Qubtiyah, yang sebelumnya beragama Kristen Koptik. Semua ini menggambarkan keakraban hubungan antara Kristen dan Islam. Bertitik tolak dari bukti-bukti yang diberikan tersebut, Rasyid Ridha berkesimpulan bahwa pada dasarnya, agama Kristen memang tidak berten- tangan dengan ajaran Islam. Pertentangan tercipta tidak lain berasal dari para penganut agama Kristen yang menyimpang. Oleh karena itu, lanjut Ridha, yang memperoleh peringatan keras 
Konfrontasi: Jurnal Kultur, Ekonomi dan Perubahan Sosial, 3 (1) Januari 2016, 8-23

P-ISSN: 1410-881X (Print)

Moh. Shofan, Pluralisme Agama Bukan Nihilisme: Respon Untuk Kaum Fundamentalis

DOI: -

http://www.konfrontasi.net/index.php/konfrontasi2

adalah penganutnya yang me- nyimpang dari jalan yang diberikan oleh Isa as. Terhadap hal ini, Charis Waddy (seorang pemuka Kristen) berkomentar sebagai berikut: " The Quran criticizes both Christian and Jews for neglecting the truths their Scriptures teach, and misunderstanding them. It can be admitted with humility that there is truth in this criticism "(Al-Qur'an mengkritik penganut Kristen dan Yahudi atas kelalaian serta kesalah-pahaman atas kebenaran-kebenaran yang diajarkan oleh kitab-kitab suci mereka. Dengan segala kerendahan hati kritik tersebut dapat diakui bahwa terdapat kebenaran atas kritik tersebut).

Keakraban yang terjalin antara Islam pada masa formatifnya dan umat Kristen jauh berbeda dengan hubungan Islam dan penganut Yahudi. Peng- anut Yahudi dari segi doktrin dan hukum lebih mendekati Syar'ah Islam. Sayangnya, hubungan Islam-Yahudi berkembang cenderung ke arah per- musuhan. Penyebab utama memburuknya hubungan keduanya ialah ulah beberapa kelomppok Yahudi yang berusaha mengusir dan membunuh Nabi Muhammad, selain konspirasi mereka dengan Arab Jahiliyah Mekkah dalam rangka menggagalkan misi Islam (QS. 9: 13). Aksi Yahudi tersebut dijawab umat Islam dengan mengumumkan perang terhadap suku-suku Yahudi, khususnya terhadap Banu Qaynuqa', Banu Nadir, dan Banu Quraizah, yang kemudian disusul dektrit Nabi Muhammad untuk mengusir segenap penghuni Yahudi dari Madinah. Permusuhan antara kelompok Yahudi dan umat Islam juga terekam dalam Al-Qur'an ( QS. 5:82).21

Dalam pandangan Amin Abdullah, secara normatif-doktrinal, al-Qur'an telah mengantisipasi kemungkinan timbulnya sikap dan budaya saling men- cemooh dan merendahkan antara kelompok yang satu dengan yang lain. Tindakan mencemooh dan mengejek, serta merendahkan orang, apalagi kelompok lain, merupakan cikal bakal dan sumber konflik sosial yang potensial. Untuk itu Al-Qur'an mengingatkan dengan tegas sebagai berikut:

"Hai orang-orang yang beriman, janganlah suatu kaum mengolok- olokkan kaum yang lain (karena) boleh jadi mereka (yang di olok- olokkan) lebih baik daripada mereka (yang mengolok-olokkan) dan jangan pula wanita-wanita (mengolok-olokkan) wanita lain karena boleh jadi wanita-wanita (yang diperolok-olokkan) lebih baik daripada yang mengolok-olok; dan janganlah kamu penggil-memanggil dengan gelar- gelar yang buruk. Seburuk-buruknya panggilan ialah (panggilan) yang buruk sesudah iman (seperti sebutan fasik, kafir, dan lain-lain pen.) dan barang siapa yang tidak bertobat, maka mereka itulah orang-orang yang zalim."

Lebih tegas lagi, tidak hanya perbuatan olok-mengolok yang tidak dibe- narkan oleh AlQur'an, bahkan tindakan "berprasangka " pun diharapkan dijauhi oleh umat manusia yang beriman.

"Hai orang-orang yang beriman, jauhilah kebanyakan dari prasangka, sesungguhnya sebagian prasangka itu adalah dosa dan janganlah kamu mencari-cari kesalahan orang lain dan janganlah sebagian kamu meng- gunjing sebagian yang lain. Sukakah salah seorang kamu memakan daging saudaranya yang sudah mati? Tentulah kamu merasa jijik kepa- danya. Bertakwalah kepada Allah. Sesungguhnya Allah Maha penerima tobat lagi Maha Penyayang."

Kedua ayat tersebut, kemudian diakhiri dengan seruan yang bersifat transkultural dan transreligius;

"Hai manusia, sesungguhnya Kami menciptakan kamu dari seorang laki- laki dan seorang perempuan dan menjadikan kamu berbangsa-bangsa dan bersuku-suku supaya kamu saling mengenal, sesungguhnya orang yang paling mulia di antara kamu di sisi Allah ialah orang yang paling bertakwa di antara kamu. Sesungguhnya Allah Maha Mengetahui lagi Maha Mengenal." 
Konfrontasi: Jurnal Kultur, Ekonomi dan Perubahan Sosial, 3 (1) Januari 2016, 8-23

P-ISSN: 1410-881X (Print)

Moh. Shofan, Pluralisme Agama Bukan Nihilisme: Respon Untuk Kaum Fundamentalis

DOI: -

http://www.konfrontasi.net/index.php/konfrontasi2

Dengan memperhatikan cara membaca ayat-ayat Al-Qur'an secara dialektis dan hermeneutis, dapat dikatakan bahwa secara doktrinal-normatif sesung- guhnya Al-Qur'an jauh lebih liberal dan radikal sekaligus arif dalam me- nanggapi isu pluralitas agama. Dengan tegas Al-Qur'an lebih menganjurkan untuk saling "berkenalan”, "bersahabat" (li ta'arafu), "berdialog" (jadilhum billati hiya ahsan), dan tidak memerlukan pemaksaan untuk menganut agama tertentu termasuk agama Islam (la ikraha fi al-din).

Penafsiran inklusif dengan mencari kemungkinan alternatif seperti di atas, misalnya, direpresentasikan oleh orang-orang semacam Mohammed Arkoun, Hassan Hanafi, Fazlur Rahman, Nurcholish Madjid, dan lain-lain. Bagi mereka, teks merupakan sumber inspirasi, resource untuk melakukan adaptasi dan adjustment. Karenanya kausus teks yang dianggap secara legalistik qath'i atau baku, berkaitan dengan hukum, harus direinterpretasi, apalagi karena jumlahnya sedikit sekali.

\section{Pluralisme Bukan Relativisme-Nihilisme}

Karena teks Al-Qur'an hadir untuk dibaca dan dipahami, maka dalam setiap proses pemahaman, juga terjadi proses penafsiran di situ. Adakah ini berarti membiarkan relativisme terhadap pemahaman Al-Qur'an?

Pada umumnya, umat beragama menganggap bahwa relativisme adalah momok yang sangat ditakuti dan sekaligus dijahui. Relativitas begitu berwajah sangat "negatif" dan merupakan sesuatu yang harus ditolak. Mengapa? karena dalam bayangan para pendukungnya, relativisme pasti mengandung arti tidak adanya standar-satandar akibat atau nilai yang kukuh, tegas dan baku atau penolakan terhadap "kebenaran umum". Relativisme seolah-olah mesti diidentikkan dengan nihilisme moral dan value vacuum. Secara implisit dan bahkan secara eksplisit, relativisme juga mengandung arti bahwa seluruh pendapat, pandangan dan keyakinan agama-agama mempunyai "nilai yang sama". Disebabkan adanya berbagai konotasi yang begitu negatif, orang beragama cenderung menolak paham "eksklusif" dan lebih mendukung truth claim. Tanpa benar-benar disadari bahwa pilihan yang ini pun dalam batas-batas yang melampaui kewajaran juga dapat dengan mudah mengantarkan seeorang atau kelompok pada sikap fundamentalisme, ekstrimisme, dan radikalisme. Persoalannya adalah sedemikian buruk dan menakutkankah wajah dan gambaran tentang "relativitas"?

Untuk menjelaskan kata relativisme, ada baiknya kita kaitkan dengan emapat kata lainnya yang diharapkan bisa menerangkan satu terhadap yang lain, yaitu: absolutisme, relativisme, obyektivisme, subjektivisme, dan nihi- lisme. Dalam wacana keagamaan, kata absolut biasanya dimaksudkan untuk mengungkapkan adanya kebenaran mutlak yang dimaknai oleh orang yang beriman, sehingga kebenaran itu tidak bisa dibantah lagi. Konsep absolut bisa ditemui dalam wacana teologi dan filsafat, bisa juga dalam kaidah ilmu fiqih, yakni yang berupa diktum AlQur'an yang diyakini jelas dan sudah final kebenarannya. Sebaliknya, nihilisme berpandangan dalam hidup ini tak ada nilai atau kebenaran yang absolut. Karena paham nihilisme tak lagi mengakui adanya sumber atau fondasi kebenaran final, maka semua konsep nilai telah tersekularkan dan, akhirnya, sesuatu hanya dinilai pada nilai tukarnya untuk kepentingan praktis duniawi. Secara padat dan singkat nihilisme dirumuskan oleh Gianni Vatimo:

"Nihilism is the situation in whict the human subject explicitly recognizes that the lack of foundation is a constitutive part of its condition (what Nietzsche calls elsewhere' the death of God"

Jika diartikan secara bebas, nihilisme adalah satu kehidupan di mana manusia secara tegas mengingkari adanya landasan yang dianggap mutlak, yang oleh Nietzsche di ekspresikan 
Konfrontasi: Jurnal Kultur, Ekonomi dan Perubahan Sosial, 3 (1) Januari 2016, 8-23

P-ISSN: 1410-881X (Print)

Moh. Shofan, Pluralisme Agama Bukan Nihilisme: Respon Untuk Kaum Fundamentalis

DOI: -

http://www.konfrontasi.net/index.php/konfrontasi2

sebagai "kematian Tuhan". Lebih lanjut Vatimo mengatakan, karena faham nihilisme tidak mengaku sumber yang absolut, maka mereka memandang teks tak ubahnya bagaikan rentetan jejak yang tidak memiliki batas akhir, orang berlari dari teks ke teks, dari penafsiran ke penasiran yang tak berkesudahan dan akhirnya akan sampai pada ujung nihilisme.

Kemudian kata objektivisme mengandaikan adanya penghadapan serta pengambilan jarak antara subjek-subjek yang hanya dimungkinkan secara teoritis dalam kajian ilmu alam. Lalu di mana letak relativisme? dengan menggunakan metode hermeneutika untuk memahmai teks alQur'an, maka pengertian relativisme berada di antara garis absolutisme dan nihilisme.

Dalam kaitan ini, kita bisa membedakan antara, "theistik relativism" dan "nihilistik relativism". Menarik kita renungkan sebuah contoh ketika seo- rang ulama menulis kitab keagamaan di mana pada akhir pembahasannya, ia senantiasa menulis: wa Allah a'lam bi alShawab. Artinya, ia mengakui "hanya Allah Yang Maha Mengetahui kebenaran". Ungkapan ini jelas sebuah peryataan betapa relatifnya pemahaman manusia atas al-Qur'an dan ilmu

Tuhan. Dengan demikian, sebuah pemahaman dan interpretasi terhadap al- Qur'an tidak bisa dikategorikan sebagai pengetahuan absolut, karena bagai- manapun, ia merupakan produk penalaran manusia. Ketika pemahaman terhadap al-Qur'an secara ontologis diabsolutkan maka ia telah menyamai atau bahkan menyaingi al-Qur'an sendiri. Jadi, merelatifkan pemahaman al- Qur'an tidak serta merta terjatuh pada nihilisme. Dengan demikian, produk pemahaman dan penasiran terhadap al-Qur'an yang didasari iman meru- pakan penghubung antara yang absolut dan yang relatif, antara yang sakral dan profan. Artinya, pemahaman kita terhadap teks al-Qur'an bersifat relatively absolut. Ia relatif karena produk nalar yang serba terbatas, namun memiliki nilai absolut karena yang dikaji dan diimani adalah firman Tuhan. Sampai batas tertentu, kapasitas nalar manusia dan firman Tuhan pasti mempunyai kesinambungan, mengingat keduanya merupakan ciptaaan Tuhan sendiri yang telah didesain sedemikian rupa agar nalar dan firman- Nya bisa saling berhubungan.

Dalam pandangan Amin Abdullah, relativitas dan relativisme di sini dipa- hami sebagai suatu cara untuk "membuka kesempatan bagi pemahaman sebuah objek dari berbagai dimensi serta aspek yang ada". Jadi, relativitas sama sekali bukan dipahami sebagai sebuah sikap penolakan secara total terhadap nilai-nilai ajaran-ajaran agama tertentu yang sudah baku.

Relativitas -agaknya Amin Abdullah lebih suka memakai istilah relativitas dari pada relativisme- di sini bukannya berarti penolakan total terhadap adanya standar umum, nilainilai fundamental keagamaan, prinsip-pinsip tauhid dan sebagainya. Relativitas sekaligus pluralitas di sini, lebih dimak- sudkan sebagai istilah "teknis metodologis" yang justru sangat dibutuhkan dalam dunia pemahaman penafsiran dan pemaknaan karena istilah tersebut dimaksudkan sebagai gambaran atau potret kenyataan betapa perbedaan budaya, agama, bahasa, dan tradisi memberikan gambaran tentang dunia termasuk dunia realitas keagamaan yang juga berbeda antara yang satu dengan yang lainnya. Kenyataan adanya hubungan yang kukuh antara "pemikiran "dan "objek pemikiran" (yang plural) merupakan pengukuhan tentang perlunya langkah-langkah dan "prosedur" pemahaman yang harus dilalui, dan bukannya simbol kekosongan atau keputusan moral.

Dengan demikian, persoalan relativitas di sini lebih terkait pada aspek "metodologis", dan bukannya pada persoalan metafisis. Relativitas di sini terkait dengan perlunya sebuah "model" penafsiran dan "kerangka pema- haman" yang besifat praktis, dan bukannya suatu peryataan yang bersifat objektif tentang sifat-sifat pokok (nature) dari dunia dan sekitar kita. Oleh karena itu, konsekuensinya, "model" atau "kerangka" pemahaman dan penafsiran tersebut 
Konfrontasi: Jurnal Kultur, Ekonomi dan Perubahan Sosial, 3 (1) Januari 2016, 8-23

P-ISSN: 1410-881X (Print)

Moh. Shofan, Pluralisme Agama Bukan Nihilisme: Respon Untuk Kaum Fundamentalis

DOI: -

http://www.konfrontasi.net/index.php/konfrontasi2

bukannya merupakan suatu pendapat yang bersifat "tetap" (tidak berubah-ubah), melainkan sekedar "model" atau "kerangka" (frame) pendekatan untuk menjelaskan hakikat segala sesuatu.

Oleh karena itu, relativitas yang penulis maksudkan bukan bermakna nihilisme moral atau juga merupakan "kekosongan nilai" (value vacuum) dan lebih-lebih lagi bukan pula sebagai "kekosongan Akidah". Akan tetapi, justru lebih merupakan upaya yang sungguh-sungguh dan autentik, khusus- nya bagi seluruh umat beragama untuk bersama-sama memahami dan membangun sebuah "makna", dan "nilai" yang lebih mendalam yang dimiliki oleh berbagai suku, ras, agama, dan sebaginya. Hal demikian rupanya lebih kondusif untuk mengantisipasi berbagai tantangan perubahan zaman.

Mengakui dan menghargai keragaman dan perbedaan agama sesungguhnya juga merupakan bagian dari doktrin al-Qur'an, meskipun tidak berarti al- Qur'an membenarkan semua agama yang ada. Namun yang pasti, baik menurut al-Qur'an maupun berdasarkan kenyataan historis-sosiologis, proses sekularisasi dan munculnya pluralisme agama dan keberagaman merupakan bagian dari hukum sejarah sunatullah di mana al-Qur'an sendiri memberikan isyarat bahkan akomodasi bagi perkembangan tersebut. Salah satu persoalan yang sering muncul dikalangan tokoh agama adalah, mereka seringkali mengingkari kenyataan ini dan kemudian mendambakan terwu- judnya agama tunggal dimuka bumi ini. Ini adalah suatu kemustahilan dan bertentangan dengan cetak biru Tuhan.

Dalam kerangka ini, gerakan puritanisasi yang digelar oleh sejumlah ormas Islam tentu merupakan aksi pengingkaran atas watak Islam yang pluralis. Meminjam sudut pandang Hermeneutika Gadamerian,26 Islam adalah sebuah "teks" yang terbuka untuk selalu direproduksi sesuai horison pem- baca. Umat Islam Indonesia dengan warna-warni budayanya berada pada posisi sebagai pembaca "teks Islam" sehingga memiliki otoritas penuh untuk menerjemahkan Islam secara berlainan dengan Islam masa awal atau corak Islam di kawasan dunia manapun. Umat Islam Indonesia berhak merepro- duksi Islam dalam semangat keindonesiaan.

Harold Coward, dalam 'Pluralisme Tantangan Bagi Agama-agama', menya- takan bahwa dunia selalu memiliki pluralitas keagamaan.27 Pada tahun 1980-AN dunia mengakui sesuatu yang belum pernah terjadi sebelumnya, yaitu hancurnya batas-batas budaya, ras, bahasa dan geografis. Dunia Barat maupun Timur tidak bisa lagi saling menutup diri, karena dewasa ini setiap orang adalah tetangga dekat dan tetangga rohani yang lain.

Untuk menghadapi realitas dunia yang plural ini, umat beragama pun dituntut untuk mampu menempatkan diri dan memahami konteks plu- ralisme yang dilandasi oleh semangat saling menghormati dan menghargai keberadaan umat beragama lain. Oleh karena itu, ada beberapa pengertian pluralisme yang perlu dipahami oleh masing-masing umat beragama.

Pertama, pluralisme tidak semata menunjuk pada kenyataan tentang adanya kemajemukan. Namun yang dimaksud adalah keterlibatan aktif terhadap kenyataan kemajemukan tesebut. Pluralisme agama dan budaya dapat kita jumpai dimana-mana. Di dalam masyarakat tertentu, di kantor tempat kita kerja, di sekolah tempat kita belajar, bahkan di pasar di mana kita berbe- lanja. Namun seorang baru dapat dikatakan menyandung sifat tersebut apabila ia dapat berinteraksi secara positif dalam lingkungan kemajemukan tersebut. Dengan kata lain, pengertian pluralisme agama dalah bahwa tiap pemeluk agama dituntut bukan saja untuk mengakui keberadaan dan hak agama lain, tapi juaga terlibat dalam usaha memahami perbedaan dan persamaan guna tercapainya kerukunan dalam kebhinekaan.

Kedua, pluralisme harus dibedakan dengan kosmopolitanisme. Kosmo- politanisme menunjuk pada suatu realitas diamana aneka ragam agama, ras, dan bangsa hidup berdampingan 
Konfrontasi: Jurnal Kultur, Ekonomi dan Perubahan Sosial, 3 (1) Januari 2016, 8-23

P-ISSN: 1410-881X (Print)

Moh. Shofan, Pluralisme Agama Bukan Nihilisme: Respon Untuk Kaum Fundamentalis

DOI: -

http://www.konfrontasi.net/index.php/konfrontasi2

di suatu lokasi. Namun interaksi positif antarpenduduk, khusunya dibidang agama, sangat minimal, kalaupun ada.

Ketiga, konsep pluralisme tidak dapat disamakan dengan relativisme. Seorang relativis akan berasumsi bahwa hal-hal yang menyangkut "kebe- naran" atau "nilai" ditentukan oleh pandangan hidup serta kerangka berpikir seseorang atau masyarakat. Sebagai konsekuensi dari paham relativisme agama, doktrin agama apa pun harus dinyatakan benar. Atau tegasnya "semua agama adalah sama", karena kebenaran-kebenaran agama-agama, walaupun berbedabeda dan bertentangan satu dengan lainnya, tetap harus diterima. Untuk itu, seorang relativis tidak akan mengenal, apalagi mene- rima suatu kebenaran universal yang berlaku untuk semua tempat dan segala zaman.

Keempat, pluralisme agama bukanlah sinkretisme, yakni menciptakan suatu agama baru dengan memadukan unsur tertentu atau sebagian komponen ajaran dari beberapa agama untuk dijadikan bagian integral dari agama baru tersebut.

Prof. Diana L. Eck,28 Professor of Comparative Religion and Indian Studies dan Director of the Pluralism Project di Harvard University, menekankan, “..pluralisme bukan sekedar relativisme. Pluralisme adalah pertautan komitmen antara komitmen religius yang nyata dan komitmen sekuler yang nyata. Pluralisme didasarkan pada perbedaan dan bukan kesamaan. Pluralisme, menurutnya adalah sebuah ikatan --bukan pelepasan-perbe- daan dan kekhususan." Pluralisme adalah bahasa mengenai arus, pertu- karan, dialog, dan debat.

Pluralisme adalah bahasa yang dibutuhkan oleh demokrasi agar dapat bertahan hidup.

Menurut Prof. Diana, ada tiga hal tentang pluralisme yang dapat menje- laskan arti Proyek Pluralisme.

Pertama, pluralisme bukan hanya beragam atau majemuk, Pluralisme lebih dari sekedar majemuk atau beragam dengan ikatan aktif kepada kema- jemukan tadi. Meski pluralisme dan keragaman terkadang diartikan sama, ada perbedaan yang harus ditekankan. Keragaman adalah fakta yang dapat dilihat tentang dunia dengan budaya yang beraneka ragam di Amerika Serikat dan Indonesia. Pluralisme membutuhkan keikutsertaan.

Di dunia di mana kita hidup saat ini, keragamam belaka tanpa usaha ikut dalam hubungan nyata dengan mereka yang berbeda dan tanpa usaha untuk menciptakan masyarakat yang harmonis akan menimbulkan masalah yang terus bertambah.

Kedua, pluralisme bukan sekedar toleransi. Pluralisme lebih dari sekedar toleransi dengan usaha yang aktif untuk memahami orang lain. Meskipun toleransi sudah pasti merupakan sebuah langkah ke depan dari ketidak- toleransian, toleransi tidak mengharuskan kita untuk mengetahui segala hal tentang orang lain. Toleransi dapat menciptakan iklim untuk menahan diri, namun tidak untuk memahami. Toleransi saja tidak banyak menjembatani jurang stereo-tipe dan kekhawatiran yang bisa jadi justru mendominasi gambaran bersama mengenai orang lain. Sebuah dasar yang terlalu rapuh untuk sebuah masyarakat yang kompleks secara religius.

Kini, dengan kebebasan menjalankan ibadah agama di negara kita dan di sekitar kita, sebuah masyarakat yang sejatinya pluralis harus berkembang melebihi toleransi untuk mencapai pemahaman yang konstruktif. Kita harus memiliki sekolah-sekolah yang giat mengajarkan agama-agama di dunia dalam konteks bidang studi sosial atau sejarah. Kita membutuhkan pemim- pin agama yang terlatih yang tidak hanya mampu menanamkan keyakinan 'gereja dan synagog' ke 'gereja, synagog, dan masjid yang dalam pada komunitasnya, namun juga terpelajar secara agama, dan mampu mencegah para agamawan lainnya salah menafsirkan dan mencemarkan komunitas agama lain. Toleransi tidak dapat menghilangkan ketidaktahuan kita tentang orang lain dan meninggalkan kebenaran lainnya dan kekhawatiran yang mendasari pola 
Konfrontasi: Jurnal Kultur, Ekonomi dan Perubahan Sosial, 3 (1) Januari 2016, 8-23

P-ISSN: 1410-881X (Print)

Moh. Shofan, Pluralisme Agama Bukan Nihilisme: Respon Untuk Kaum Fundamentalis

DOI: -

http://www.konfrontasi.net/index.php/konfrontasi2

lama perpecahan dan kekerasan. Di dunia yang kita tinggali ini, ketidaktahuan kita akan semakin mahal harganya.

Ketiga, bahwa pluralisme bukan sekedar relativisme. Pluralisme adalah pertautan komitmen antara komitmen religius yang nyata dan komitmen sekuler yang nyata. Pluralisme didasarkan pada perbedaan dan bukan kesamaan. Pluralisme adalah sebuah ikatan -- bukan pelepasan -- perbedaan dan kekhususan. Kita harus saling menghormati dan hidup bersama secara damai. Namun harus ditambahkan bahwa hidup bersama dalam sebuah masyarakat yang penuh semangat bukan hanya sekedar hidup berdam- pingan tanpa memedulikan orang lain. Hal itu membutuhkan ikatan, kerja- sama, dan kerja yang nyata. Ikatan komitmen yang paling dalam, perbedaan yang paling mendasar dalam menciptakan masyarakat secara bersama-sama menjadi unsur utama dari pluralisme.

Ikatan perbedaan dalam masyarakat yang pluralistik, menurut Diana L. Eck, tidaklah dibentuk berdasarkan struktur peperangan, namun struktur dialog. Ikatan yang penuh semangat, bahkan argumentasi bersama menjadi penting bagi masyarakat yang demokratis. Dengan kata lain, keyakinan beragama juga menjadi sangat penting yang didapat bukan karena kebiasaan atau warisan, namun dalam konteks dialog dengan komitmen dari mereka yang menganut keyakinan lain. Dialog seperti ini tidak ditujukan untuk mencapai kesepakatan, namun mencapai hubungan. Komitmen tidak ditinggalkan. Bahasa pluralisme adalah dialog dan pertemuan, memberi dan menerima, serta kritik dan kritik diri. Dalam dunia kita ini, bahasa inilah yang harus kita pelajari

Dengan demikian, istilah relativisme yang digunakan dalam tulisan ini - sekali lagibukan berarti nihilisme. Istilah tersebut digunakan semata-mata karena adanya perbedaanperbedaan interpretasi dan pemaknaan antara pengikut golongan agama yang satu dengan yang lain. Relativitas yang ada di sini dinilai wajar, karena beberapa faktor, yaitu: tingkat perbedaan pengalaman sejarah yang dijalani oleh suku, raja, umat, bangsa, kawulo cilik, dan golongan elit, tingkat pendidikan yang diperoleh oleh masyarakat (nomad, agraris, industri, informasi-komunikasi), dan alat-alat teknologi yang dimiliki. Belum lagi bicara tingkat jaringan kerja (networks) yang dimiliki, intensitas kontak, dan pertemuan dengan golongan atau kelompok lain. Di sinilah kita baru dapat memahami makna pluralitas agama, termasuk relativitas yang turut melekat di dalamnya. Namun, relativitas di sini sama sekali tidak mengandung maksud untuk menafikan, apalagi sampai menegasikan tujuan-tujuan luhur yang secara 'absolut' diajarkan, dimiliki, dipegang teguh oleh pengikut agama-agama. Yang jelas, ketika cita- cita, belief, credo, iman, dan akidah yang semula dianggap 'absolut' tersebut dikonseptualisasikan serta diaungkapkan melalui bahasa manusia dan diinstitusionalisasikan melalui lembaga, perkumpulan, organisasi sosial, budaya, dan agama - belum lagi jika kepentingan politik ikut terlibat dan bermain di dalamnya, maka tujuan-tujuan luhur tersebut sebenarnya telah memasuki wilayah yang bersifat historis kultural dan 'relatif'.

Dengan begitu, maka hal-hal yang 'relatif' (instrumental values) sesung- guhnya tidak dapat dengan begitu saja dipindahkan ke wilayah yang bersifat 'absolut' (ultimate values). Jika hal-hal yang sesungguhnya relatif ini diabso- lutkan atau disakralkan, maka cepat atau lambat akan terjadi disharmonisasi sosial (ketidaknyamanan, ketakutan, keterkekangan, kekakuan, keter- paksaan, ketidakbebasan, perasaan tertindas, dll.) yang pada saatnya nanti menimbulkan kekerasan (violence) dalam kehidupan sosial keagamaan baik secara fidik maupun psikologis.

Ketegangan hubungan yang bersifat perenial antara yang 'absolut' dan yang 'relatif' dalam pemikiran sosial-keagamaan hanya dapat dikurangi ketika manusiamenyadari kembali bahwa ia hanyalah makhluk yang sedang ber- proses secara terusmenerus. Ketika proses 
Konfrontasi: Jurnal Kultur, Ekonomi dan Perubahan Sosial, 3 (1) Januari 2016, 8-23

P-ISSN: 1410-881X (Print)

Moh. Shofan, Pluralisme Agama Bukan Nihilisme: Respon Untuk Kaum Fundamentalis

DOI: -

http://www.konfrontasi.net/index.php/konfrontasi2

tersebut berlangsung, tidak ada yang disebut 'absolut' dalam arti yang sebenar-benarnya, dan juga tidak ada yang disebut 'relatif' dalam arti yang sebenar-benarnya.

Karenanya, pluralisme sebagai desain Tuhan (design of God) harus diamal- kan berupa sikap dan tindakan yang menjunjung tinggi multikulturalisme. Namun tidak sekedar berhenti pada wacana pentingnya pluralisme dan multikulturalisme, akan tetapi lebih diejawantahkan pada tataran praksis. Yakni, tidak pula sekedar menjadi homo pluralis yang menghargai kera- gaman hidup, melainkan juga sebagai homo multikulturalis yang berke- yakinan bahwa relasi pluralitas yang di dalamnya terdapat problem mino- ritas vs mayoritas, harus dibangun dengan tindakan nyata berdasarkan pengakuan atas persamaan, kesetaraan, dan keadilan. Wallahu a'lam bi al- Shawab.

\section{Bibliografi}

Abdullah, M. Amin, Falsafah Kalam di Era Postmodernisme, (Yogyakarta: Pustaka Pelajar, 1997).

Abdullah, M. Amin, Studi Agama: Normativitas Atau Historisitas? (Yogya- karta: Pustaka Pelajar, 1996)

Rahman, Munawar, Budhy, "Teologi Pluralisme di Persimpangan Jalan", wawancara di Jaringan Islam Emansipatoris, www.islamemansipa- toris.com.

Madjid, Nurcholish, "Masyarakat Madani dan Investasi Demokrasi: Tan- tangan dan Kemungkinan", Republika, 10 Agustus 1999.

Rahman, Munawar, Budhy, Islam Pluralis Wacana Kesetaraan Kaum Beriman, (Jakarta: Paramadina, 2001)

Madjid, Nurcholish, Islam Doktrin dan Peradaban Sebuah Telaah Kritis tentang Masalah Keimanan, Kemanusiaan dan Kemodernan (Jakar- ta: Paramadina, 1992).

Nadroh, Siti, Wacana Keagamaan dan Politik Nurcholish Madjid, (Jakarta: PT Raja Grafindo Persada, 1999).

Sachedina, Abdulaziz, "Negara Tidak Punya Hak Mengurusi Keimanan”,www.islamlib.com.

Fanani, Fuad, Ahmad, "Islam, Pluralisme, dan Kemerdekaan Beragama, "www.islamlib.com.

Rahman, Fazlur, Major Themes of the Qur'an (Chicago: Bibliotheca Islami- ca, 1980)

Madjid, Nurcholish, Atas Nama Pengalaman Beragama dan Berbangsa Di Masa Transisi (Kumpulan Dialog Jum'at di Paramadina), (Jakarta: Paramadina, 2002).

Madjid, Nurcholish, dkk., Fiqh Lintas Agama Membangun Masyarakat Inklusif-Pluralis, (Jakarta: Paramadina, 2003).

Ghazali, Moqsith, Abdul, "Problematika Quranik Pluralisme Agama “, Media Indonesia, 6 Agustus, 2004.

Anwar, Bihar, Ramli, Cecep, "Menyegarkan Wacana Ahli Kitab” www.Islamlib.com.

Shihab, Alwi, Membedah Islam di Barat Menepis Tudingan Meluruskan Kesalahpahaman (Jakarta: PT. Gramedia Pustaka Utama, 2004).

Abdullah, M. Amin, Dinamika Islam Kultural Pemetaan Atas Wacana Islam Kontemporer (Bandung: Mizan, 2000).

Vatimo, Gianni, The End of Modernity (Baltimore: The John Hopkins Uni- versity Press, 1991).

Hidayat, Komaruddin Menafsirkan Kehendak Tuhan (Jakarta: Teraju, 2004).

Subayu, Rony "Merayakan Pluralisme Islam", www.islamlib.com.

Coward, Harold, Pluralisme: Tantangan bagi Agama-Agama (Yogyakarta: Kanisius, t.th)

L. Eck, Diana, "Amerika Baru Yang Religius: Tantangan Pluralisme Beragama," http://cafe2.degromiest.nl/node/190

Abdullah, M. Amin, Pendidikan Agama Era Multikultural Multireligius (Jakarta: PSAP, 2005). 